\title{
Cytotoxic and apoptogenic effects of Strobilanthes crispa Blume extracts on nasopharyngeal cancer cells
}

\author{
RHUN YIAN KOH ${ }^{1}$, YI CHI SIM ${ }^{2}$, HWEE JIN TOH ${ }^{2}$, LIANG KUAN LIAM ${ }^{2}$, RACHAEL SZE LYNN ONG ${ }^{2}$, \\ MEI YENG YEW ${ }^{3}$, YEE LIAN TIONG ${ }^{4}$, ANNA PICK KIONG LING ${ }^{1}$, SOI MOI CHYE ${ }^{1}$ and KHUEN YEN NG ${ }^{3}$ \\ ${ }^{1}$ Department of Human Biology, School of Medicine; ${ }^{2}$ School of Pharmacy and Health Sciences, \\ International Medical University, Kuala Lumpur 57000; ${ }^{3}$ Jeffrey Cheah School of Medicine and Health Sciences, \\ Monash University Malaysia, Bandar Sunway, Selangor 47500; ${ }^{4}$ School of Postgraduate Studies and Research, \\ International Medical University, Kuala Lumpur 57000, Malaysia
}

Received May 14, 2014; Accepted June 3, 2015

DOI: $10.3892 / \mathrm{mmr} .2015 .4152$

\begin{abstract}
The chemotherapeutic agents used to treat nasopharyngeal cancer (NPC) exhibit low efficacy. Strobilanthes crispa Blume is widely used for its anticancer, diuretic and anti-diabetic properties. The present study aimed to determine the cytotoxic and apoptogenic effects of $S$. crispa on CNE-1 NPC cells. A 3-(4,5-dimethylthiazol-2-yl)-2,5 diphenyl tetrazolium bromide assay was used to evaluate the cytotoxic effects of $S$. crispa against CNE-1 cells. The rate of apoptosis was determined using propidium iodide staining and caspase assays. Ethyl acetate, hexane and chloroform extracts of $S$. crispa leaves all exhibited cytotoxic effects on CNE-1 cells, at a half maximal inhibitory concentration $\left(\mathrm{IC}_{50}\right)$ of $119,123.5$ and $161.7 \mu \mathrm{g} / \mathrm{ml}$, respectively. In addition, hexane, chloroform and ethyl acetate extracts of S. crispa stems inhibited CNE-1 cell proliferation, at a $\mathrm{IC}_{50}$ of $49.4,148.3$ and $163.5 \mu \mathrm{g} / \mathrm{ml}$, respectively. Flow cytometric analysis revealed an increased proportion of cells in the sub $\mathrm{G}_{1}$ phase and a decreased proportion of cells in the $\mathrm{G}_{2} / \mathrm{M}$ phase, following treatment with the extracts. However, the extracts did not alter the activities of caspase $-3 / 7,-8$ and -9 . No cytotoxic effect was observed when the cells were treated with the methanol and water extracts of $S$. crispa stems and leaves. In conclusion, the S. crispa extracts were cytotoxic against CNE-1 cells and these extracts were able to induce apoptosis, independent of caspase activation.
\end{abstract}

\section{Introduction}

Nasopharyngeal carcinoma (NPC) is a tumor, which arises from the epithelial cells of the nasopharynx. NPC can be

Correspondence to: Dr Rhun Yian Koh, Department of Human Biology, School of Medicine, International Medical University, 126 Jalan Jalil Perkasa 19, Bukit Jalil, Kuala Lumpur 57000, Malaysia E-mail: rhunyian_koh@imu.edu.my

Key words: apoptosis, cytotoxicity, Strobilanthes crispa Blume, nasopharyngeal cancer classified into three subtypes: Squamous cell carcinoma, non-keratinizing carcinoma and undifferentiated carcinoma. The exact etiology of NPC remains to be elucidated, however, it has been suggested that Epstein-Barr virus may be one of the causes of NPC, since it has been reported to be associated with epithelial cell transformation into NPC type 2 and $3(1,2)$. In addition, type 2 (non-keratinizing carcinoma) and 3 (undifferentiated carcinoma) NPCs are associated with increased titers of the virus (3). Diet, genetic factors, gender and ethnicity have also been regarded as possible risk factors of NPC.

NPC is a rare malignancy in the majority of countries, with an incidence rate of $<1$ case per 100,000 individuals annually. However, the incidence rate is higher (20-50 cases per 100,000 individuals per year) in southern China and southeast Asia. A combination of radiation and chemotherapy is the current predominant therapeutic strategy for the treatment of patients with locally and regionally confined tumors (4). However, the majority of established chemotherapies are associated with intolerable side effects, including dizziness, vomiting and constipation. Furthermore, certain patients may not respond well to treatment or may develop resistance following long term usage. Therefore, alternative medicine, including the use of medicinal plants, is becoming essential. The use of medicinal plants has been extensively investigated for several years.

Malaysia is a megadiverse country with a high number of endemic vascular plant species (5), as well as several types of medicinal plants and herbs, which have been widely used in traditional medicine. For example, Agrimony eupatoria has been used to treat diabetes (6), and Centella asiatica can be used for wound healing (7). Another well-known medicinal plant is Strobilanthes crispa Blume, which is termed pecahkaca or jinbatu in Malaysia; enyohkelo, kecibeling, kejibeling or ngokilo in Java; and daun pecahbeling in Jakarta. S. crispa is a flowering shrub, which belongs to the Acanthaceae family, and is distributed throughout regions of Madagascar to Indonesia (8). S. crispa can be readily found in forests, riverbanks and fields.

$S$. crispa has been used extensively in various regions as a traditional remedy to heal a wide range of diseases. Infusion of the dried leaves of S. crispa has been suggested to possess 
antidiabetic, diuretic, antilithic and laxative properties (9). In addition, fresh leaves may be masticated and swallowed, to benefit the immune system (10). The water extract of S. crispa has been reported to inhibit the proliferation of retroviruses (11). Previously, S. crispa extract has demonstrated inhibitory properties against breast (12-17), liver (14,16-20), prostate (12) and colon (14) carcinomas. These findings have encouraged further investigation regarding the use of this plant for its anticancer properties. There are currently no reports regarding the anticancer effects of S. crispa on NPC. Therefore, the present study aimed to determine the cytotoxic and apoptogenic effects of S. crispa on NPC. Furthermore, the mechanism of action of apoptosis through caspase activation was investigated.

\section{Materials and methods}

Plant extraction procedures. The fresh leaves and stems of S. crispa were collected from Paka (Terengganu, Malaysia), and oven dried at a temperature of $40^{\circ} \mathrm{C}$ until a constant weight was obtained. The botanical identity of the plant was determined and authenticated by a taxonomist from the Forest Research Institute Malaysia (Kuala Lumpur, Malaysia; sample number: PID 040114-04). Water and organic solvents were used to perform plant extraction. To prepare the water extract, $10 \mathrm{~g}$ dried $S$. crispa was mixed with $500 \mathrm{ml}$ distilled water and maintained at $60^{\circ} \mathrm{C}$ for $3 \mathrm{~h}$. The resulting suspension was then filtered and freeze-dried. In addition, stepwise extraction using solvents of increasing polarity (hexane, chloroform, ethyl acetate and methanol) was performed to prepare the organic solvent extracts (14). Briefly, $100 \mathrm{~g}$ dried S. crispa was mixed with $500 \mathrm{ml}$ organic solvent and maintained in the dark for 3 days at room temperature. The samples were subsequently filtered using Whatman paper (Thermo Fisher Scientific, Waltham, MA, USA) and the resulting filtrates were evaporated using a rotary evaporator (Buchi R-2154; Buchi, Flawil, Switzerland). Finally, 10 different plant extracts were obtained, as follows: Leaves hexane (LH), leaves chloroform (LC), leaves ethyl acetate (LEA), leaves methanol (LM), leaves water (LW), stems hexane (SH), stems chloroform (SC), stems ethyl acetate (SEA), stems methanol (SM) and stems water (SW).

Cell culture. The CNE-1 human NPC cell line was provided by Professor Sam Choon Kook (Institute of Biological Sciences, University Malaya, Kuala Lumpur, Malaysia), and the NRK-52E normal neonatal rat kidney epithelial cell line was purchased from American Type Culture Collection (Manassas, VA, USA). The cell lines were cultured in Dulbecco's modified Eagle's medium (Gibco Life Technologies, Carlsbad, CA, USA) supplemented with $10 \%$ fetal bovine serum (Gibco Life Technologies), $100 \mathrm{U} / \mathrm{ml}$ penicillin and $100 \mu \mathrm{g} / \mathrm{ml}$ streptomycin, at $37^{\circ} \mathrm{C}$ in an incubator with $5 \% \mathrm{CO}_{2}$.

Cell viability assay. A 3-(4,5-dimethylthiazol-2-yl)-2,5 diphenyl tetrazolium bromide (MTT) assay was performed to assess the viability of the cells. Briefly, the CNE-1 or NRK-52E cells were seeded in 96-well plates at a density of $1 \times 10^{5}$ cells $/ \mathrm{ml}$ and treated with various concentrations of plant extracts $(12.5,25,50,100$ and $200 \mu \mathrm{g} / \mathrm{ml})$ at $37^{\circ} \mathrm{C}$ for $72 \mathrm{~h}$.
The cells were also treated with the known anti-cancer drug, 5-fluorouracil (Sigma-Aldrich) at the concentrations of 12.5, $25,50,100$ and $200 \mu \mathrm{g} / \mathrm{ml}$. The cytotoxicity of the extracts of NPC cells was compared with the effect of 5-fluorouracil. MTT (10 $\mu \mathrm{l}$; Biobasic, Amherst, NY, USA) was then added to each well and incubated for an additional $4 \mathrm{~h}$ prior to removal of the media. Dimethyl sulfoxide (Friendemann Schmidt, Parkwood, WA, USA) was subsequently added to dissolve the formazan product. The absorbance was read at $570 \mathrm{~nm}$ wavelength, with the results expressed as a percentage of cell viability using the following formula: Optical density (OD) sample/OD control x 100\%. A dose-response curve was plotted, and the half maximal inhibitory concentration $\left(\mathrm{IC}_{50}\right)$ of the extracts were determined through interpolation from the curve. The extracts that exhibited cytotoxic activity were used in the following assays for the determination of cell proliferation and apoptosis. The control cells in the present study represent untreated cells.

The selectivity index (SI) was calculated from the $\mathrm{IC}_{50}$ ratio of NRK-52E and CNE-1 cells. The SI value indicates the selectivity of the sample to the cell lines assessed. Samples with an SI value $>3$ were considered to have high selectivity (21).

Morphological assessment of cells. The CNE-1 cells $\left(1 \times 10^{6}\right.$ cells per well of 6 -well plate) were treated with various extracts at their $\mathrm{IC}_{50}$ concentration for $72 \mathrm{~h}$ at $37^{\circ} \mathrm{C}$. Morphological changes of the cells were observed under an inverted microscope (Nikon Eclipse TS100; Nikon Corporation, Tokyo, Japan) and micrographs were captured.

Determination of population doubling time (PDT). The PDT was calculated to estimate the duration of the cell cycle and compare the effects of the extracts. The cells were counted using a manual hemocytometer (Marienfeld, Lunda-Königshofen, Germany). Briefly, $1 \times 10^{4} \mathrm{CNE}-1$ cells were seeded into a 24-well plate and treated with the various extracts at their $\mathrm{IC}_{50}$ concentration for $72 \mathrm{~h}$ at $37^{\circ} \mathrm{C}$. Subsequently, the number of cells were counted following staining with trypan blue (Gibco Life Technologies). The PDT was calculated by dividing the total duration (h) by the total number of generations. The number of generations was calculated by $3.32\left(\log \mathrm{N}_{\mathrm{N}^{-}}-\log \mathrm{N}_{1}\right)$, where $\mathrm{N}_{\mathrm{N}}$ is the number of cells counted and $\mathrm{N}_{1}$ is the number of cells inoculated (22).

Flow cytometric analysis. The cells $\left(1 \times 10^{6}\right.$ cells per well of 6-well plate) were treated with the plant extracts at their respective $\mathrm{IC}_{50}$ concentrations for $72 \mathrm{~h}$ at $37^{\circ} \mathrm{C}$ were harvested and fixed in $70 \%$ ethanol. Following two washes with cold phosphate-buffered saline, $500 \mu 1$ propidium iodide (20 $\mu \mathrm{g} / \mathrm{ml}$; Sigma-Aldrich, St. Louis, MO, USA) and $500 \mu \mathrm{l}$ RNase (Sigma-Aldrich) was added to the cells. Flow cytometric analysis (FACScan; BD Biosciences, Franklin Lakes, NJ, USA) was performed following 30 min incubation, in order to investigate the rate of cell apoptosis.

Caspase activity assay. The Apo-ONE ${ }^{\circledR}$ Homogeneous Caspase-3/7 Assay kit was purchased from Promega Corporation (Madison, WI, USA) and the Caspase- 8 and- 9 Assay kits were obtained from Calbiochem (Merck KGaA, Darmstadt, Germany). The CNE-1 cells were treated with the 
Table I. $\mathrm{IC}_{50}(\mu \mathrm{g} / \mathrm{ml})$ and selectivity index values of extracts of Strobilanthes crispa on CNE-1 and NRK-52E cells.

\begin{tabular}{|c|c|c|c|c|}
\hline \multirow[b]{2}{*}{ Plant material } & \multirow[b]{2}{*}{ Extract/treatment } & \multicolumn{2}{|c|}{$\mathrm{IC}_{50}(\mu \mathrm{g} / \mathrm{ml})$} & \multirow[b]{2}{*}{ Selectivity index } \\
\hline & & CNE-1 & NRK-52E & \\
\hline \multirow[t]{5}{*}{ Leaves } & Hexane & $123.50 \pm 37.50$ & $84.00 \pm 1.41$ & 0.68 \\
\hline & Chloroform & $161.70 \pm 20.20$ & $184.50 \pm 12.02$ & 1.14 \\
\hline & Ethyl acetate & $119.00 \pm 48.10$ & $166.50 \pm 2.12$ & 1.40 \\
\hline & Methanol & N/A & N/A & - \\
\hline & Water & N/A & N/A & - \\
\hline \multirow[t]{5}{*}{ Stems } & Hexane & $49.40 \pm 8.00$ & $11.00 \pm 2.83$ & 0.22 \\
\hline & Chloroform & $148.30 \pm 23.20$ & N/A & $>1.35$ \\
\hline & Ethyl acetate & $163.50 \pm 16.30$ & $174.00 \pm 5.66$ & 1.06 \\
\hline & Methanol & N/A & N/A & - \\
\hline & Water & N/A & N/A & - \\
\hline- & 5-fluorouracil & $3.05 \pm 1.15$ & $9.60 \pm 4.81$ & 3.15 \\
\hline
\end{tabular}

$\mathrm{IC}_{50}$ values are expressed as the mean \pm standard deviation of three independent experiments. N/A, Not available; $\mathrm{IC}_{50}$; half maximal inhibitory concentration; SD, standard deviation.

different plant extracts at their $\mathrm{IC}_{50}$ concentrations for $72 \mathrm{~h}$, following which the activities of caspase $3 / 7,-8$ and -9 were measured using the above-mentioned kits. The detection of caspase activity was performed, according to the manufacturer's instructions.

Statistical analysis. The results are presented as the mean \pm standard deviation. The data were subjected to one-way analysis of variance using GraphPad Instat version 3.0 (GraphPad Software, Inc., La Jolla, CA, USA). P <0.05 was considered to indicate a statistically significant difference.

\section{Results}

Cytotoxicity of $S$. crispa extracts. A summary of the $\mathrm{IC}_{50}$ of the extracts on CNE-1 cells is presented in Table I. Of all the extracts assessed, LH, LC, LEA, SH, SC and SEA resulted in CNE-1 cell death. The hexane extract of $S$. crispa stems exhibited the most potent cytotoxic effect against the CNE-1 cells, with an $\mathrm{IC}_{50}$ value as low as $49.4 \pm 8.0 \mu \mathrm{g} / \mathrm{ml}$. Following the hexane extract, the order of cytotoxicity was as follows: LEA $>$ LH $>$ SC $>$ LC $>$ SEA extracts of $S$. crispa. Methanol and water extracts of the $S$. crispa leaves and stems caused no significant inhibition of cell growth of CNE-1 cells.

The cytotoxicity of the extracts on NRK-52E cells was also assessed. Similar observations were noted in the NRK-52E cells as the CNE-1 cells. SH exhibited the most potent activity against the NRK-52E cells, with the lowest $\mathrm{IC}_{50}$ value. However, it was not possible to determine the $\mathrm{IC}_{50}$ value of SC. Overall, all of the extracts in the present study exhibited a low SI, with values ranging between 0.22 and 1.40 .

The anticancer drug 5-fluorouracil exhibited potent activity against $\mathrm{CNE}-1$ cell growth, with a low $\mathrm{IC}_{50}$ value $(3.05 \pm 1.15 \mu \mathrm{g} / \mathrm{ml})$ and high SI (3.15).

Antiproliferative effects of $S$. crispa extracts. As shown in Fig. 1, all the plant extracts prolonged the PDT of the cells, with

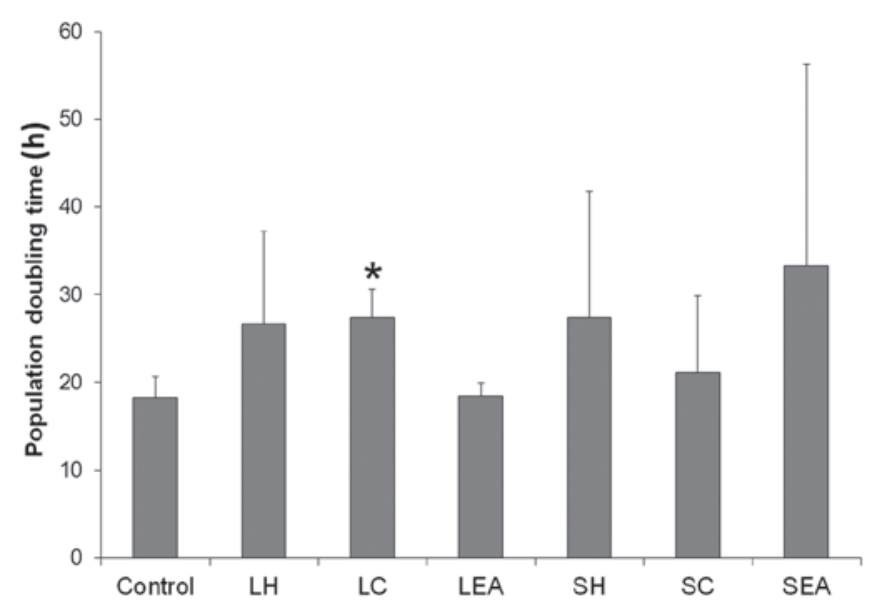

Figure 1. Effects of Strobilanthes crispa extracts on the population doubling time of CNE-1 nasopharyngeal carcinoma cells. Cells were treated with various plant extracts for $72 \mathrm{~h}$, and the number of cells was counted to determine the population doubling time. Data are presented as the mean \pm standard deviation of three independent experiments. ${ }^{*} \mathrm{P}<0.05$, compared with the control. $\mathrm{LH}$, leaves hexane; LC, leaves chloroform; LEA, leaves ethyl acetate; SH, stems hexane; SC, stems chloroform; SEA, stems ethyl acetate.

the exception of LEA. Treatment with SC resulted in marginal increase in PDT, compared with the control cells, whereas the cells treated with LH, LC and SH exhibited a 2 -fold increase in PDT. Treatment with SEA increased PDT by $82.50 \%$; however, of the extracts assessed, only LC increased the PDT with statistical significance $(\mathrm{P}<0.05)$.

Effects of S. crispa on CNE-1 cell morphology. The normal morphology of CNE-1 cells is shown in Fig. 2A. The cells appeared attached among each other and well-organized. The cells treated with the various plant extracts (Figs. 2B-G) exhibited distinct morphological changes, compared with the control cells; with apoptotic bodies and floating dead cells. In 




Figure 2. Microscopic images of treated and untreated CNE-1 nasopharyngeal cells. Morphology of the (A) untreated and (B-G) Strobilanthes crispa extract-treated CNE-1 cells under an inverted microscope following $72 \mathrm{~h}$ incubation. The cells were treated with the half maximal inhibitory concentration of the extract. White block arrow indicates apoptotic bodies; white line arrow indicates floating dead cells; white dashed arrow indicates empty spaces due to cell detachment.

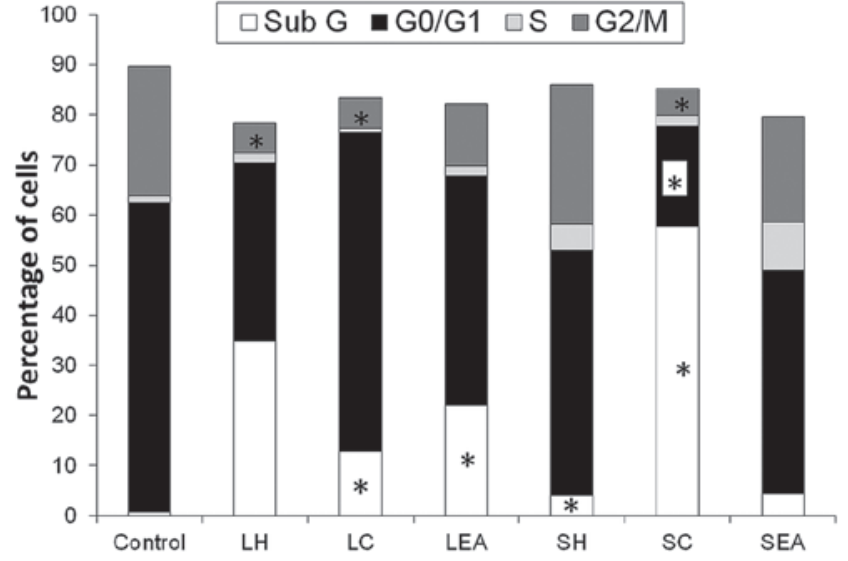

Figure 3. Flow cytometric analysis of cell cycle distribution of the control and Strobilanthes crispa-treated CNE-1 nasopharyngeal carcinoma cells. The CNE-1 cells were treated with the extracts at their respective half maximal inhibitory concentrations for $72 \mathrm{~h}$, followed by staining with propidium iodide. Data are presented as the mean of three independent experiments. ${ }^{*} \mathrm{P}<0.05$, compared with the control. $\mathrm{LH}$, leaves hexane; LC, leaves chloroform; LEA, leaves ethyl acetate; SH, stems hexane; SC, stems chloroform; SEA, stems ethyl acetate.

addition, a reduction in the number of cells was observed in the extract-treated wells.

Apoptogenic effects of S. crispa on CNE-1 cells. As shown in Fig. 3 , the percentage of control cells in the sub $\mathrm{G}$ phase $(0.69 \%)$

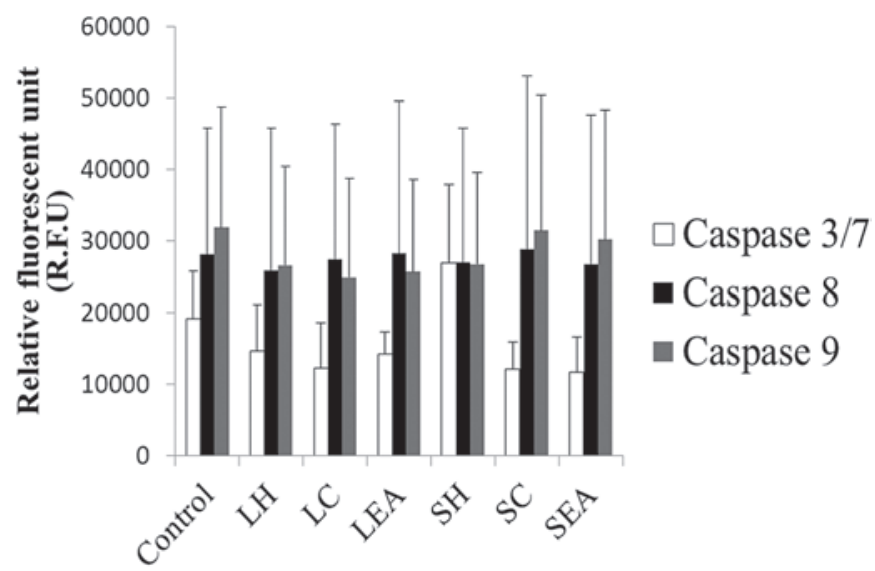

Figure 4. Caspase activity in CNE-1 nasopharyngeal carcinoma cells following treatment with various Strobilanthes crispa extracts for $72 \mathrm{~h}$. The CNE-1 cells were treated with the extracts at their respective half maximal inhibitory concentrations, and the fluorescent expression of caspases was measured. Data are presented as the mean \pm standard deviation of three independent experiments. No statistically significant differences were detected between the groups. LH, leaves hexane; LC, leaves chloroform; LEA, leaves ethyl acetate; SH, stems hexane; SC, stems chloroform; SEA, stems ethyl acetate.

increased significantly to 12.85 and $22.08 \%$ following treatment with LC and LEA, respectively $(\mathrm{P}<0.05)$. The percentage of cells in the sub $\mathrm{G}$ phase was also markedly increased by SC $(57.67 \%)$ and moderately increased by SH $(4.07 \% ; \mathrm{P}<0.05)$. Treatment with SC also reduced the percentage of cells in the $\mathrm{G}_{0} / \mathrm{G}_{1}$ phase by $67.55 \%$. A significant reduction in the number 
of cells in the $\mathrm{G}_{2} / \mathrm{M}$ phase was also observed following treatment of the cells with LH, LC and SC $(\mathrm{P}<0.05)$.

Effects of $S$. crispa on caspase activation. As shown in Fig. 4, treatment with all the extracts, with the exception of $\mathrm{SH}$, decreased the levels of caspase 3/7 in the CNE-1 cells. However, no marked changes were observed in the levels of caspase- 8 and -9 . None of these differences observed in caspase activities were statistically significant.

\section{Discussion}

The principle behind the MTT assay is the reduction of yellow tetrazolium salt to purple formazan by reductase enzyme of viable cells, and this conversion directly reflects the number of viable cells. Therefore, an MTT assay was used in the present study to determine the cytotoxicity of plant extracts of S. crispa on CNE-1 NPC cells.

The $\mathrm{IC}_{50}$ values of the $S$. crispa extracts on CNE-1 cells are summarized in Table I. The cytotoxic effects exhibited by $S$. crispa extracts in the present study were concordant with the findings of a previous study by Rahmat et al (23). The previous study demonstrated that bioactive compounds isolated from $S$. crispa leaves exhibit anticancer properties towards a certain cancer cell lines. The bioactive compounds were identified as $\beta$-sitosterol and stigmasterol (23). However, there may be other bioactive compounds that are able to inhibit cancer growth in $S$. crispa, requiring further investigation of the isolation and purification of the active compounds. Liza et al (24) observed the presence of flavonoids, (+)-catechin, (-)-epicatechin, rutin, myricetin, luteolin, apigenin, naringenin and kaempferol, in S. crispa. The consumption of vegetables and fruits rich in flavonoids has previously been associated with a decreased cancer risk $(25,26)$; therefore, these flavonoids may also contribute to the anticancer properties of $S$. crispa.

In the present study, the hexane extract of $S$. crispa stems exhibited the most potent cytotoxic effect against the CNE-1 cells. These results suggested that the active compounds in $S$. crispa are of low polarity, as cytotoxic effects were detected in samples extracted with solvents of low polarity, including hexane. Hexane has been identified as a suitable solvent for the extraction of non-polar compounds, including oils and fats. A previous study successfully isolated anthraquinones from the roots of Cratoxylum formasum as a potent anticancer agent using hexane (27). In the present study, the $\mathrm{IC}_{50}$ value of SH extract was markedly lower than that of the LH extract (Table I). This many indicate that the active compounds responsible for the anticancer property of $S$. crispa are more abundant in the stems, compared with the leaves.

Methanol and water extracts from S. crispa leaves and stems did not cause CNE-1 cell death. This result was consistent with that of a previous study, which demonstrated that the water extract of $S$. crispa did not exhibit a cytotoxic effect toward any of the cancer cell lines assessed (13). These results suggested that the polar compounds extracted by methanol or water had a less toxic effect against cancer cells.

Previous studies have indicated that crude extracts of S. crispa have no cytotoxic effect against Chang liver cells (12). In the present study, the cytotoxicity of S. crispa was assessed on NRK-52E normal kidney epithelial cells, since kidneys serve as the excretory organ of metabolized drugs. The results of the present study demonstrated that the extracts that exhibited a cytotoxic effect towards the CNE-1 cells also inhibited proliferation of the NRK-52E cells, with the exception of SC. The $\mathrm{IC}_{50}$ value of SC on NRK-52E cells was not determined, even at the highest concentration $(200 \mu \mathrm{g} / \mathrm{ml})$ of the plant extract. Therefore, SC had a higher SI index ( $>1.35)$, compared with the other extracts, suggesting that SC is safer to use as an anticancer agent.

PDT is the average duration required for successful cell division, and is used an indicator of cell proliferation. As shown in Fig. 1, treatment with LC significantly increased the PDT. These results suggested that the effect of LC on CNE-1 cell growth inhibition, detected by the MTT assay, may be due to the ability of LC to decrease the rate of cell proliferation.

The stimulation of apoptosis and inhibition of cell proliferation remain the most effective anticancer treatment strategies; therefore, the therapeutic induction of apoptosis has been used as a model for the development of antitumor drugs (28). In the present study, apoptotic features of cells were observed under the microscope. Quantitative measurement of apoptosis was performed by propidium iodide staining of DNA, analyzed using flow cytometry. The flow cytometric assay aimed to detect cells in the sub- $\mathrm{G}_{1}$ phase, resulting from DNA fragmentation (29).

As shown in Figs. 2B-G, CNE-1 cell morphology was markedly altered following treatment with the S. crispa extracts. Apoptotic features, as well as dead cells, were observed. The cells were subsequently subjected to cell cycle distribution analysis using flow cytometry. The results demonstrated that the percentage of cells in the sub- $\mathrm{G}_{1}$ phase increased, and the percentage of cells in the $\mathrm{S}$ and $\mathrm{G}_{2} / \mathrm{M}$ phases decreased following treatment with the S. crispa extracts. These results indicated that the extracts induced apoptosis and fewer CNE-1 cells entered into the synthesis phase and mitotic cycle. Reduced proliferation of the CNE-1 cells was noted in the present study, following treatment with the S. crispa extracts. There was a positive correlation between the inhibition of cell proliferation and inhibition of cell cycle progression, due to the increased proportion of cells in the sub- $G_{1}$ phase, together with the decreased proportion of cells in the $\mathrm{G}_{2} / \mathrm{M}$ phase (30). Furthermore, distinctive morphological changes associated with apoptosis, including apoptotic body formation (31), were prevalent in the extract-treated CNE-1 cells. These results suggested that $S$. crispa may induce CNE-1 cell death through the apoptotic mechanism. However, further assessments for apoptosis, including annexin-V staining, a comet assay and a terminal deoxynucleotidyl transferase dUTP nick-end labeling assay are required in the future to confirm these results. In addition, investigation of the apoptosis-mediated mechanisms is required for better understanding of the effects of $S$. crispa at the molecular level, therefore the present study detected caspase activation.

Caspases belong to a group of enzymes known as cysteine proteases, which act as important mediators of signal transduction in apoptosis. Caspase- 8 and -9 are regarded as two key initiators of apoptosis, the death receptor-mediated and mitochondrion-mediated pathways. By contrast, caspase-3/7 are responsible as effectors in executing apoptosis by cleaving key cellular substrates, thus leading to apoptotic cell death (32). As shown in Fig. 4, no significant changes in caspase levels were observed in the CNE-1 cells treated with the S. crispa extracts, 
compared with the untreated cells. These results suggested that caspase-mediated apoptosis may not be the sole process of apoptotic cell death induced by S. crispa. The other possible mechanism of action of apoptosis may be via downregulation of the expression of c-myc, lysosomal proteases (33) or granzyme release (34), which require further investigation. Several studies have suggested that downregulation of the expression of c-myc may be necessary for the induction of apoptosis in leukemia cells (35), macrophage cells (36), prostate cancer (37) and lung cancer (38). Notably, a previous study demonstrated that chloroform extract of $S$. crispa suppressed the expression of c-myc expression in cancer (18), suggesting the important role of c-myc in mediating the effects of S. crispa.

In conclusion, hexane, chloroform and ethyl acetate extracts of S. crispa leaves and stems exerted potent cytotoxic effects against CNE-1 cells. The extracts also induced apoptosis by increasing the sub- $\mathrm{G}_{1}$ population, and the effects were independent of caspase-3, -7 and -9 activation. Based on the observations of the present study, these extracts may serve as potential anticancer agents. Therefore, isolation of active compounds from S. crispa extracts and evaluation of their anti-cancer effects in vivo may be performed in the future.

\section{Acknowledgements}

This study was supported by the International Medical University (Kuala Lumpur, Malaysia; no. BPharm B0108_ Res082011).

\section{References}

1. Wolf $\mathrm{H}$, zur Hausen $\mathrm{H}$ and Becker V: EB viral genomes in epithelial nasopharyngeal carcinoma cells. Nat New Biol 244: 245-247, 1973.

2. Lo YM, Chan LY, Lo KW, Leung SF, Zhang J, Chan AT, Lee JC, Hjelm NM, Johnson PJ and Huang DP: Quantitative analysis of cell-free Epstein-Barr virus DNA in plasma of patients with nasopharyngeal carcinoma. Cancer Res 59: 1188-1191, 1999.

3. Neel HB III, Pearson GR and Taylor WF: Antibodies to Epstein-Barr virus in patients with nasopharyngeal carcinoma and in comparison groups. Ann Otol Rhinol Laryngol 93: 477-482, 1984.

4. Tabuchi K, Nakayama M, Nishimura B, Hayashi K and Hara A: Early detection of nasopharyngeal carcinoma. Int J Otolaryngol 2011: 638058, 2011.

5. Australian State of the Environment Committee 2001, Australia State of the Environment 2001, Independent Report to the Commonwealth Minister for the Environment and Heritage. CSIRO Publishing on behalf of the Department of the Environment and Heritage, Canberra.

6. Gray AM and Flatt PR: Actions of the traditional anti-diabetic plant, Agrimony eupatoria (agrimony): Effects on hyperglycaemia, cellular glucose metabolism and insulin secretion. $\mathrm{Br}$ J Nutr 80: 109-114, 1998.

7. Gohil KJ, Patel JA and Gajjar AK: Pharmacological review on Centella asiatica: A potential herbal cure-all. Indian J Pharm Sci 72: 546-556, 2010.

8. Burkill IH, Birtwistle W, Foxworthy FW, Scrivenor JB and Watson JG (eds): A Dictionary of the Economic Products of the Malay Peninsula. Vol 2. Crown Agents for the Colonies, London, pp2086-2087, 1935.

9. Perry LM and Metzger J (eds): Medicinal plants of east and south east Asia. Attributed properties and uses. MIT press, Cambridge, MA, pp452-617, 1980.

10. Samuel AJ, Kalusalingam A, Chellappan DK, Gopinath R, Radhamani S, Husain HA, Muruganandham V and Promwichit P: Ethnomedical survey of plants used by the Orang Asli in Kampung Bawong, Perak, West Malaysia. J Ethnobiol Ethnomed 6: 5, 2010.
11. Kusumoto JT, Shimada I, Kakiuchi N, Hattori M, Supriyatna S and Namba T: Inhibitory effects of Indonesian plant extracts on reverse transcriptase of an RNA tumour virus (I). Phytother Res 6: 241-244, 1992.

12. Yaacob NS, Hamzah N, Nik Mohamed Kamal NN, Zainal Abidin SA, Lai CS, Navaratnam V and Norazmi MN: Anticancer activity of a sub-fraction of dichloromethane extract of Strobilanthes crispus on human breast and prostate cancer cells in vitro. BMC Complement Altern Med 10: 42, 2010.

13. Muslim NS, Ng KW, Itam A, Nassa ZD, Ismail Z and Abdul Majid AMS: Evaluation of cytotoxic, anti-angiogenic and antioxidant properties of standardized extracts of Strobilanthes crispus leaves. International Journal of Pharmacology 6: 591-599, 2010.

14. Rahmat A, Endrini S, Md Akim A, Ismail P, Taufiq Y, Yun H and Abu Bakar MF: Anticarcinogenic properties of Strobilanthes crispus extracts and its compounds in vitro. Int J Cancer Res 2: 47-49, 2006.

15. Chong HZ, Rahmat A, Yeap SK, Md Akim A, Alitheen NB, Othman F and Gwendoline-Ee CL: In vitro cytotoxicity of Strobilanthes crispus ethanol extract on hormone dependent human breast adenocarcinoma MCF-7 cell. BMC Complement Altern Med 12: 35, 2012.

16. Endrini S, Rahmat S, Ismail P and Taufiq-Yap YH: Comparing of the cytotoxicity properties and mechanism of Lausonia inermis and Strobilanthes crispus extract against several cancer cell lines. J Med Sci 7: 1098-1102, 2007.

17. Ng KW, Salhimi SM, Majid AM and Chan KL: Anti-angiogenic and cytotoxicity studies of some medicinal plants. Planta Med 76: 935-940, 2010.

18. Endrini S, Suherman, Rahmat A, Ismail P, Taufiq-Yap YH and Othman F: Effects of Strobilanthes crispus extract on the apoptotic pathway of human liver carcinoma cell lines. Jurnal Kedorkteran Yarsi. 15: 1-5, 2007.

19. Hanachi P, Othman F and Rahmat A: Lesion scoring and P450 isoenzyme activity in liver of hepatocarcinogenesis rats treated with Strobilanthes crispus. Iranian Journal of Cancer Prevention 1: 12-16, 2008.

20. Suherman J, Rahmat A, Othman F, Ismail P and Nor Haslinda A: Effect of Strobilanthes crispus on tumour marker enzymes and glutathione during chemical hepatocarcinogenesis in the rat. Pakistan J Biol Sci 7: 947-951, 2004.

21. Mahavorasirikul W, Viyanant V, Chaijaroenkul W, Itharat A and Na-Bangchang K: Cytotoxic activity of Thai medicinal plants against human cholangiocarcinoma, laryngeal and hepatocarcinoma cells in vitro. BMC Complement Altern Med 10: 55, 2010.

22. Schoene NW and Kamara KS: Population doubling time, phosphatase activity, and hydrogen peroxide generation in Jurkat cells. Free Radic Biol Med 27: 364-369, 1999.

23. Rahmat A, Edrini S, Ismail P, Taufiq Y, Yun $\mathrm{H}$ and $\mathrm{Abu}$ Bakar MF: Chemical constituents, antioxidant activity and cytotoxic effects of essential oil from Strobilanthes crispus and Lawsonia inermis. J Biol Sci 6: 1005-1010, 2006.

24. Liza MS, Abdul Rahman R, Mandana B, Jinap S, Rahmat A, Zaidul ISM and Hamid A: Supercritical carbon dioxide extraction of bioactive flavonoid from Strobilanthes crispus (Pecah Kaca). Food Bioprod Process 88: 319-326, 2010.

25. Ferguson PJ, Kurowska E, Freeman DJ, Chambers AF and Koropatnick DJ: A flavonoid fraction from cranberry extract inhibits proliferation of human tumor cell lines. J Nutr 134: 1529-1535, 2004.

26. Jain R and Jain SK: Screening of in vitro cytotoxic activity of some medicinal plants used traditionally to treat cancer in Chhattisgarh state, India. Asian Pac J Trop Biomed S147-S150, 2011.

27. Boonsri S, Karalai C, Ponglimanont C, Kanjana-opas A and Chantrapromma K: Antibacterial and cytotoxic xanthones from the roots of Cratoxylum formosum. Phytochemistry 67: 723-727, 2006.

28. Wang TS, Chen LJ, Zhang ST, Lin JM and Wang ZY: Purified alkaloids extract from Scutellaria barbata inhibits proliferation of nasopharyngeal carcinoma CNE-1 cells by inducing apoptosis and cell cycle arrest at S phase. J Med Plants Res 5: 3687-3696, 2011.

29. Tayarani-Najaran Z, Emami SA, Asili J, Mirzaei A and Mousavi SH: Analyzing cytotoxic and apoptogenic properties of Scutellaria litwinowii root extract on cancer cell lines. Evid Complementary Alternat Med 2011: 160682, 2011.

30. Yi ZC, Wang H, Zhang GY and Xia B: Downregulation of connexin 43 in nasopharyngeal carcinoma cells is related to promoter methylation. Oral Oncol 43: 898-904, 2006. 
31. Hu ZY, Zhu XF, Zhong ZD, Sun J, Wang J, Yang D and Zeng YX: ApoG2, a novel inhibitor of antiapoptotic Bcl-2 family proteins induces apoptosis and suppresses tumor growth in nasopharyngeal carcinoma xenografts. Int J Cancer 123: 2418-2429, 2008.

32. Riedl SJ and Shi Y: Molecular mechanisms of caspase regulation during apoptosis. Nat Rev Mol Cell Biol 5: 897-907, 2004.

33. Stoka V, Turk B, Schendel SL, Kim TH, Cirman T, Snipas SJ, Ellerby LM, Bredesen D, Freeze H, Abrahamson M, et al: Lysosomal protease pathways to apoptosis: Cleavage of bid, not pro-caspases, is the most likely route. $\mathrm{J}$ Biol Chem 276 3149-3157, 2001

34. Barry M, Heibein JA, Pinkoski MJ, Lee SF, Moyer RW, Green DR and Bleackley RC: Granzyme B short-circuits the need for caspase 8 activity during granule-mediated cytotoxic T-lymphocyte killing by directly cleaving Bid. Mol Cell Biol 20: 3781-3794, 2000.
35. Alneri ES, Fernandes TF, Halder S, Croce CM and Litwack G: Involvement of BCL-2 in glucocorticoid-induced apoptosis of human pre-B-leukemias. Cancer Res 52: 491-495, 1992.

36. Oritani K, Kaisho T, Nakajima K and Hirano T: Retinoic acid inhibits interleukin-6-induced macrophage differentiation and apoptosis in a murine hematopoietic cell line, Y6. Blood 80: 2298-2305, 1992.

37. Balaji KC, Koul H, Mitra S, Maramag C, Reddy P, Menon M, Malhotra RK and Laxmanan S: Antiproliferative effects of c-myc antisense oligonucleoride in prostate cancer cells: A novel therapy in prostate cancer. Urology 50: 1007-1015, 1997.

38. Van Waardenburg RC, Meijer C, Burger H, Nooter K, De Vries EG, Mulder NH and De-Jong S: Effects of an inducible anti-sense c-myc gene transfer in a drug-resistant human small-cell-lung-carcinoma cell line. Int J Cancer 73: 544-550, 1997. 